\title{
Momentum investing: evidence from the US tourism and hospitality
}

\author{
Mohamed Shaker Ahmed \\ Business Administration, Cairo University, Cairo, Egypt
}

\begin{abstract}
Purpose - The present research aims to examine a range of momentum trading strategies for the tourism and hospitality sector.

Design/methodology/approach - The paper followed the methodology of Jegadeesh and Titman (1993) to construct the portfolios. In this methodology, all portfolios were formed and evaluated by their cumulative stock returns over the past $J$ periods and holding the position for the next $K$ periods. In total, nine formation and holding periods were used, represented by 3, 6 and 12. For example, strategy 3-3 (that is, strategy with $J=3$ and $K=3$ ) refers to the strategy that stocks are ranked based on their previous three months and then held for the next three months.

Findings - The findings demonstrated that none of these momentum investing strategies was profitable. Most of the results, however, show positive, but insignificant momentum returns. This finding can be interpreted as price reversal over a horizon of three to twelve months in the US hospitality and tourism sector. These results are robust to size, different formation and holding combinations, beta and turnover.

Research limitations/implications - Regarding the research limitations, this paper only considers the US tourism and hospitality sector. Therefore, the extension of results to other developed and developing markets should be taken carefully. Also, this paper relies only on the methodology of Jegadeesh and Titman (1993). Other methodologies could be suitable avenues for future research.

Practical implications - Investors and portfolio managers who seek for earning abnormal returns by investing in the US HT stocks can attain their hopes by constructing portfolios based on existing guidelines in the literature and adopting a short-term reversal trading strategy or by buying past losers and selling past winners of the US tourism and hospitality stocks.

Originality/value - This research contributes to the hospitality finance literature by offering the investors who are interested in the US hospitality and tourism sector an uncomplicated trading rule that uses real return data and is expected to generate actual returns. Moreover, the momentum strategy of Jegadeesh and Titman (1993) is never used in the hospitality finance literature.
\end{abstract}

Keywords Momentum, Trading strategies, Short-term reversal, Jegadeesh and Titman 1993, Hospitality and tourism stocks

Paper type Research paper

\section{Introduction}

Are momentum trading strategies profitable for the US "tourism and hospitality" stocks (hereafter HT)? There are two reasons why this question is particularly important. First, from a corporate point of view, financial markets provide long-term, stable sources of finance, especially because the HT industry requires intensive capital investment. Second, the HT industry is crucial for economic growth and many are interested in investing in this industry.

\section{JEL Classification - G10, G11, G12, G14, G40}

(c) Mohamed Shaker Ahmed. Published in European Journal of Management and Business Economics. Published by Emerald Publishing Limited. This article is published under the Creative Commons Attribution (CC BY 4.0) licence. Anyone may reproduce, distribute, translate and create derivative works of this article (for both commercial and non-commercial purposes), subject to full attribution to the original publication and authors. The full terms of this licence may be seen at http:// creativecommons.org/licences/by/4.0/legalcode
Momentum investing

Received 15 February 2021 Revised 2 April 2021 9 April 2021

11 April 2021 16 April 2021

Accepted 17 April 2021

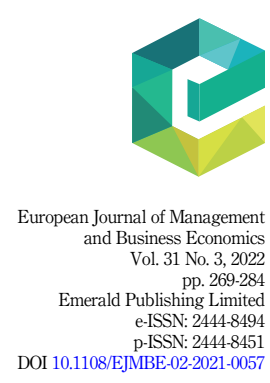


EJMBE 31,3
The economic importance of this industry for economic growth comes from the following factors:

First, the HT sector worldwide contributes significantly to inflows of hard currencies, equilibrium in the trade balance, employment rates and economic growth. According to Lim and Chan (2013), the HT sector contributed US $\$ 6$ trillion or $9 \%$ of total global gross domestic product (GDP) in 2011 and over 2.84 million employment opportunities (Hsu, 2017). Moreover, the HT stocks have attracted increased attention over the last years. For instance, the total initial public offerings (IPOs) have increased by US $\$ 565 \mathrm{~m}$ in 2013 with 7\% first-day return, and two of the top three IPOs performers were from the HT industry - Potbelly Corporation and Noodles and Company - where the prices of both doubled on the first trading day (Borghesi et al., 2015). Furthermore, the number of stocks in the US stock market increased from 5,425 in 1981 to 8,485 in 1999 (by over 113\%). Besides, more than $\$ 626$ bn of personal consumption in the US in 2010 went to food services and accommodation. In the United States, the country of interest, the HT is the most important sector. In 2017, foreign and US citizens spent more than $\$ 1,035.7$ bn on direct travel costs, providing more than $\$ 165$ bn altogether in tax revenues, and it was the largest employer in that year (US Travel Association, 2017). According to the World Tourism Organization (UNWTO), the HT industry has been the fastest-growing economic sector in the world over the past 60 years (Chang, et al., 2014).

Short-term momentum is the most documented financial anomaly in finance literature. Some scholars have emphasized that momentum trading is a puzzle because it challenges the efficient market theory, which assumes that historical data cannot be used to predict price movements (Keynes, 1936; Fama, 1965, 1998; Ritter, 2003). However, numerous studies in the finance literature provide empirical evidence that stock returns can be predicted based on historical stock prices, especially short-term momentum and long-term reversal. For example, De Bondt and Thaler (1985) demonstrate that buying losing stocks over the two to five years and selling short winning stocks over the previous two to five years earns about $8 \%$ per year. Jegadeesh and Titman (1993) focus on the short-term momentum and show that buying winning stocks over a period of three to twelve months and short selling losing stocks over a period of three to twelve months lead to making an abnormal return of $1 \%$ per month. This is why interest in momentum trading strategies in stock markets has been renewed.

This momentum strategy that entails buying past losers and selling past winners was first documented by Jegadeesh and Titman (1993). Since then, the existence of momentum in many contexts has become well-documented in the literature. For instance, Rouwenhorst (1998) examines momentum in several international markets and documents significant momentum profits in 12 European equity markets. Rouwenhorst (1999) documents positive and significant momentum returns in emerging markets. Moskowitz and Grinblatt (2002) demonstrate the existence of momentum in several different industries. Finally, momentum is also seen in commodity markets (Erb and Campbell, 2006). While increasing interest in momentum is shown in the finance literature, the applicability of momentum strategies to the US HT sector, to the best of our knowledge, has attracted only limited attention from academics and practitioners.

Finance literature documents two broad explanations about why momentum exists in the stock market: risk-based and behavioral-based. The risk-based theory demonstrates that momentum profits are just compensation for risk (Conrad and Kaul, 1998). The behavioralbased explanation attributes the momentum either to behavioral biases (Barberis et al., 1998; Daniel et al., 1998; Grinblatt and Han, 2005) or to limitations of arbitrage that may prevent arbitrage and, in turn, prevent the mispricing from being corrected (Sadka, 2006; Shleifer, 2000; Shleifer and Vishny, 1997; Shiller, 1984). The term for the existence and persistence of these instances of mispricing is financial anomalies, of which momentum is an example, which creates predictability in stock returns. 
The key contribution of this paper is the offering of a new investment strategy that uses real data and generates actual returns rather than expected returns in the US HT. The momentum strategy of Jagadeesh and Titman (1993) is never used in the hospitality finance literature, although it is widely used in the finance literature and among finance scholars and technical analysts. This study also gives the investors who are interested in the US HT sector uncomplicated trading rules that use real data and are expected to generate actual returns.

The present research aims to examine a range of momentum trading strategies for the HT sector following the methodology of Jegadeesh and Titman (1993). The range of formation and holding periods is 3,6 and 12 . Several robustness checks were conducted to examine the stability of the estimators by dividing the sample into two separate parts using size, beta and turnover and to support the main results. Our findings are of interest because they contradict a wide range of papers and evidence in the literature. The key findings of this paper show that not all momentum trading strategies are profitable, a finding which is robust to size, different formation and holding combinations, beta and turnover.

\section{Literature review}

The HT sector is worth a separate investigation because of its many unique fundamental characteristics: (1) It depends on the ALFO-business model (an asset-light and fee-oriented strategy). This strategy focuses more on loyalty-based assets, such as technology, franchising and management contracts and less on physical assets such as hotels and restaurants. According to Li and Singal (2019), this strategy reduces risk because it helps corporations to grow and expand; (2) HT companies are characterized by high leverage due to large investments in fixed assets, higher risk and stronger competition compared with other industries and high in capital intensity (Ahmad and Adaoglu, 2018) and (Dewally, et al., 2017); (3) It is among the sectors with the lowest cash holdings in the economy (Kim, et al., 2011); (4) It requires intensive initial investment because it invests heavily in facilities such as buildings and real estate to increase sales in current facilities, open new facilities and engage in acquisition (Dewally, et al., 2017); (5) the ratio of institutional and managerial ownership has lately increased substantially. More than $50 \%$ of hotels are owned by private equity funds, real estate investment trusts and institutional investors (Kim and Jang, 2018) and (6) Traditional macroeconomic variables have limited explanatory power to predict stock returns (Ersan et al., 2019). So far, to the best of our knowledge, no empirical work has examined the momentum trading strategies in HT, either in the finance literature or in HT finance literature. Finally, Chen et al. (2005) attest that the HT industry experienced noise trading similar to other industries such as construction, finance, electronics, transportation, [1] and wholesale and retail.

Scholars studied many aspects of the US HT stocks. For instance, Nowak (1993) argues that the HT industry requires large amounts of initial investment and is capital-intensive. This means that the US hospitality stocks are sensitive to changes in the monetary policy in general and to changes in interest rates in particular. Dewally et al. (2017) have found that hospitality companies prefer to undertake their large investments when the current sales growth is high, market volatility is low or the leverage is low. In the same context, Chen et al. (2005) provide evidence that Taiwanese hospitality stocks are affected significantly by economic variables and monetary policy variables. Ming-Hsiang Chen used Taiwanese stock prices in his work with Kim and Chen et al. (2007) to examine the existence of mean reversion behavior among hospitality stocks. In the hospitality sector, they found that earnings per share (EPS) is a good proxy for the fundamental values of stock prices, and there is a longterm convergence relationship between EPS as a proxy for fundamental values and stock prices. The findings also confirmed that a lower level of noise trading and lack of small size effect characterizes the hospitality sector, so that stock prices are more likely to be driven by their fundamental value proxied by EPS.

Momentum investing 
EJMBE 31,3
One of the above authors, Ming-Hsiang Chen (2012) compared the buy and hold trading strategy with the timing strategy from January 2, 1973 to May 30, 2008. His findings show that the buy and hold strategy is poor and that the timing strategy outperformed the buy and hold strategy for US hospitality stocks. With the timing strategy, investors buy HT stocks when the discount rate is decreasing and get rid of these stocks when the discount rate is increasing; they invest their money entirely in treasury bills. Then in 2013, MingHsiang Chen divided the sample into bull and bear markets to examine whether the response of HT to the monetary policy news was symmetric or asymmetric. The findings reveal that the response of HT stocks to monetary news differs between bull markets and bear markets. Cheung and Lam (2015) conducted interesting research on what is called sin stocks. They compared the stock returns of sin stocks (stocks of casino companies, crosslisted stocks that are listed on the Hong Kong and US stock markets). The findings show that sin stocks experience high daily returns and high volatility proxied by standard deviation compared with market indices, and sin stocks in Hong Kong generate higher abnormal returns than these stocks in the US stock market. They attribute the difference between the abnormal returns in Hong Kong and the US to the different cultural characteristics of the two localities.

Lee et al. (2013) focus on online travel agencies and try to identify the determinants of systematic risk in the industry. The findings show that advertising expenditure, liquidity and firm size are the most important determinants. Meanwhile, Singal (2012) examines the predictive power of consumer sentiment on hospitality stock returns and indicates that consumer sentiment, at least in part, is a good predictor for hospitality stock returns. Chang and Zeng (2011) find that positive investor sentiment and the impact of this sentiment on stock returns outperform any other economic factors. Oak and Dalbor (2008) observe that institutional investors tend to possess large lodging stocks, high capital expenditure-to-asset ratio and high debt ratio. Continuing with institutional investors, Leung and Lee (2006) divide them into high and low examples. The findings indicate that tourism stocks with higher institutional ownership generate greater Monday returns than tourism stocks with lower institutional ownership. Shahzad and Caporin (2020) demonstrate that oil volatility plays an important role in the financial performance of tourism companies.

Jalkh et al. (in press) provide evidence that oil-implied volatility is more appropriate to hedge the downside risk of US travel and leisure stocks than the implied volatility of US stocks. Ersan et al. (2019) reveal that the impact of uncertainty in European and global economic policy on the stock returns of travel and leisure companies is significantly negative. Lee and Jang (2007) investigate the determinants of systematic risk using a sample of 16 US airline companies from 1997 through 2002. The findings indicate that profitability, growth and safety are significantly and negatively related to systematic risk, while leverage and size are significantly and positively related to systematic risk.

Recently, Jareno et al. (in press) used a quantile regression model to investigate the validity of the Fama-French Five-Factor model (2015) to predict the stock returns of hospitality firms. Using a sample of 12 European companies, the findings support the superiority of the quantile regression model over the ordinary least square estimator in predicting the stock returns of hospitality firms. Aharon (in press) demonstrates that the consumer sentiment index and the consumer confidence index are better than the economic policy uncertainty index and the volatility index in predicting stock returns of tourism and leisure firms. Qin et al. (2021) found a positive relationship between oil prices and stock returns of travel and leisure firms using a sample of Chinese firms from January 2000 to December 2018 and the impact of policy uncertainty on stock returns to be sometimes positive and at other times negative.

Hospitality finance theory stipulates that the monetary policy has a strong predictive power in the HT industry because the need for large initial investments characterizes this 
industry. Therefore, the HT industry is sensitive to changes in interest rates (Collier and Gregory, 1995; Chen, 2010; Goukasian et al., 2012). Chen (2013) reveals that hospitality stock returns respond differently to changes in the monetary policy in the bear market compared to those changes in the bull market. In the same context, Barrows and Naka (1994) state that three macroeconomic factors may play an important role in predicting stock returns in the US HT industry, namely, the growth rate in money supply, changes in domestic consumption and changes in inflation rate. Lim and Chan (2013) study the determinants of HT stock returns in New Zealand using the arbitrage pricing theory and find that market risk, money supply and discount rate are good predictors for HT stock returns.

Chen (2010) contradicts the previous study and explains that there is no relationship between discount rate and hospitality stock return. Therefore, the discount rate has no predictability power on hospitality stock returns. Singal (2012) provided evidence that consumer sentiment plays a role in predicting hospitality stock returns. Demir et al. (2017) confirm that the prediction of hospitality stock returns needs to consider eight macroeconomic variables, namely, consumer price index, imports, exchange rate, consumer confidence index, oil price, money supply, foreign tourist arrivals and monthly market return. Finally, Ersan et al. (2019) document that the European and global economic policy uncertainties are negatively and significantly related to hospitality stock returns.

The key shortcomings of the above studies are as follows: (1) Some econometric techniques and models are too sophisticated to be used by practitioners. (2) Some models required tracking more than time series of macroeconomic variables, which may lead to confusion because of the contradictory indications of these variables. (3) The use of these variables may be viable for some times but nonviable for others and the sign of each variable may differ from one time period to another. (4) It is noticed that there is no consensus on which variables are the most important in the US HT and each study offers a distinct set of variables.

I hypothesize that financial anomalies such as momentum and reversal may exist among the HT stocks in the United States. The explanation for this hypothesis is that the US HT stocks experience noise trading in the stock market (Chen et al., 2005). These noise traders commit systematic behavioral errors that may either prevent them from processing the information rationally, such as overconfidence, representativeness heuristics, underreaction and overreaction, or deprive them of having complete information, such as having information on only some securities not all securities in the market, making mistakes in forecasting due to the investors' prior beliefs, not knowing the structural relationships in the economy or not knowing the correct data-generating process. Thus, these traders can be considered the key factor deviating the stock prices away from the fundamental value and destabilizing the market prices because they commit systematic mistakes or depend on improper probability assessment and sometimes trade using irrelevant information, resulting in a reduction in the market efficiency because they take positions and actions that prevent the new information from incorporating into prices, which keeps the prices away from the fundamental values and create some sort of predictability, e.g. momentum and reversal in stock returns (Brav and Heaton, 2002; Bloomfield et al., 2009). My first hypothesis can then be stated:

H1. Ceteris paribus, financial anomalies are expected to exist among the US HT stocks.

\section{Methodology}

\subsection{Data}

This paper used a total of 301 firms with 24,272 observations from the US HT sector. These firms are the largest in the US stock market since they are extracted from the Russell 3,000 index. Monthly data were collected from Bloomberg covering 246 months. The following

Momentum investing 
EJMBE 31,3 tourism subindustries traded in NYSE, AMEX and NASDAQ were selected: (1) Transportation by air (two-digit SIC $=45$ ), (2) Transportation services (two-digit $\mathrm{SIC}=47$ ), (3) Eating and drinking places (two-digit SIC = 58), (4) Hotels, rooming houses, camps and other lodging places (two-digit SIC $=70$ ) and Amusements and recreation services (two-digit SIC $=79$ ).

\section{4}

\subsection{The methodology of Jegadeesh and Titman (1993)}

The paper followed the methodology of Jegadeesh and Titman (1993) to construct the portfolios. In this methodology, the overlapping technique was used, and all portfolios were formed and evaluated by their cumulative stock returns over the past $J$ periods, holding the position for the next $K$ periods. Then, at the end of each $J$ period, the stocks were ranked depending on past cumulative returns and were divided into ten equally weighted portfolios. In total, nine formation and holding periods were used, represented by 3, 6 and 12. For example, strategy 3-3 (that is, strategy with $J=3$ and $K=3$ ) refers to the strategy that stocks are ranked based on their previous three months and then held for the next three months. For all momentum strategies, one month was skipped between the formation and holding period to avoid the possible bias of bid-ask spread. Following Chui et al. (2003), the $30 \%$ breakpoint for winner and loser portfolios was chosen instead of the traditional $10 \%$ breakpoint, due to the small size of our sample. The methodology of Jegadeesh and Titman (1993) can be explained by Figure 1. All stocks in the sample are segmented into ten equally weighted portfolios. Each portfolio is constructed based on the past returns over the $J$ periods and is ranked ascendingly.

The top decile (decile 1) in the above figure is the winner portfolio while the bottom decile is the loser portfolio (decile 10). All of the above positions, long and short, should be closed out at the end of every month and replaced by new deciles. Also, in every month $t$, there are many overlapping portfolios where each portfolio is constructed from buying the winner portfolio (decile 1) and selling short the loser portfolio (decile 10). Finally, the return of selling the loser portfolio, the short position, should be deducted from the return of the long position.

\section{Empirical results}

Table 1 describes the contribution of each industry to the overall sample of the HT sector. The Eating and drinking places (SIC code: 58) is the largest industry in the HT sector, with $34.22 \%$. Hotels, rooming, houses, camps and other lodging places (SIC code: 70 ) is the second largest industry, with 27.24 of the overall sample. Transportation services (SIC code: 47), in contrast, is the smallest industry in the HT sector, with $4.99 \%$.

Table 2 summarizes the mean returns, standard deviation and reward-to-risk for each momentum portfolio. The rows represent the ranking periods ( $J=3,6$ and 12 months), and the columns represent the holding periods ( $K=3,6$ and 12 months). Regarding strategies, on average momentum strategies can earn $0.107 \%$ a month, with a range from 0.01 for the $6-6$ momentum strategy to $0.267 \%$ for the 3-12 momentum strategy. The same table also reports the monthly standard deviations and reward-to-risk ratios of each portfolio. Inconsistently with the rational expectation theory, the portfolio with the highest risk or volatility (3-12) does not earn the highest reward-to-risk ratio, but the portfolio with the lowest risk or volatility $(\mathrm{SD}=0.023)$ earns the second-highest reward-to-risk $(6.261 \%)$.

Table 3 summarizes the monthly average returns of losers, winners and momentum strategies run using all the stocks in the sample size, where winners are defined as the top $30 \%$ of past returns and losers are defined as the bottom $30 \%$ of past returns. As previously mentioned, these portfolios are formed with equal weights and held for $K$ subsequent months $(K=3,6,12)$. This results in nine momentum strategies of $J$ and $K$ months. For example, 


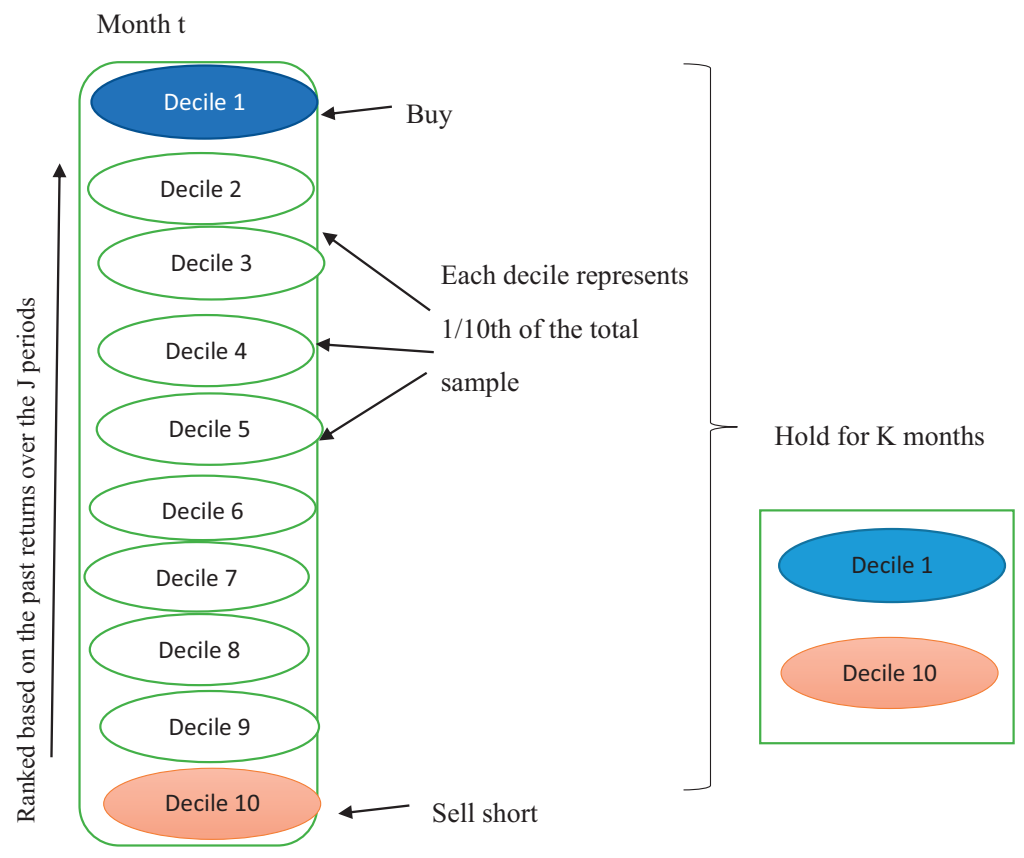

Momentum investing

Note(s): See Friedrich, p. 48

Figure 1.

Jegadeesh and Titman (1993) methodology

\begin{tabular}{llcc}
\hline SIC code & Industry & Number of firms per industry & Percentage \\
\hline 45 & Transportation by air & 49 & 16.28 \\
47 & Transportation services & 15 & 4.99 \\
58 & Eating and drinking places & 103 & 34.22 \\
70 & Hotels, rooming, houses & 82 & 27.24 \\
& camps and other lodging places & 52 & 17.27 \\
79 & Amusements and recreation services & 301 & 100
\end{tabular}

Note(s): This table reports the industries that make up the tourism and hospitality sector, showing a two-digit SIC for each, the number of companies in each industry and the proportion of each industry in the whole sample

Table 1.

The proportion of each industry in the whole sample

strategy 3-3 (that is, strategy with $J=3$ and $K=3$ ) refers to the strategy that stocks are ranked based on their previous three months and then held for the next three months. If the difference between winners' returns and losers' returns $(W-L)$ is statistically significantly greater than zero, then there is a momentum profit. Otherwise, there are no momentum profits. The results are inconsistent with those of Jegadeesh and Titman (1993) because all momentum strategies do not generate significant positive returns none of them is statistically significant and all $t$-values are statistically insignificant. Regarding loser and winner portfolios, the returns of all winner portfolios are significantly positive and vary between 0.8559 and 1.151. Similarly, the returns of all loser portfolios are also significantly positive and vary between 0.851 and 1.109 .

This finding is inconsistent with (Jegadeesh and Titman, 1993, 2001; Rouwenhorst, 1998) who found positive momentum profits over a horizon of three to twelve months. In other 
Panel A: ranking period three months

$\begin{array}{lrll}\text { Mean } & -0.253 & 0.190 & 0.267 \\ \text { St. deviation } & 0.039 & 0.038 & 0.044 \\ \text { Reward-to-risk } & -6.487 & 5 & 6.068 \\ \text { Panel B: ranking period six } & \text { months } & & \\ \text { Mean } & 0.012 & 0.010 & 0.264 \\ \text { St. deviation } & 0.031 & 0.043 & 0.042 \\ \text { Reward-to-risk } & 0.387 & 0.233 & 0.286 \\ \text { Panel B: ranking period } 12 \text { months } & & \\ \text { Mean } & 0.144 & 0.212 & 0.121 \\ \text { St. deviation } & 0.023 & 0.030 & 0.038 \\ \text { Reward-to-risk } & 6.261 & 7.067 & 3.184\end{array}$

Table 2.

Summary statistics of momentum portfolios based on $30 \%$ breakpoint
Note(s): This table presents the momentum portfolios based on $30 \%$ breakpoint. Momentum is a portfolio that buys the winner portfolio (top 30\% of stocks) and sells the loser portfolio (bottom $30 \%$ of stocks) short. Returns are measured as proportions rather than percentages. The reward-to-risk ratio is the ratio of monthly mean to the monthly standard deviation

\begin{tabular}{llccr}
\hline & & $K=3$ & $K=6$ & $K=12$ \\
\hline$J=3$ & Winners & $0.855(4.029)$ & $1.015(4.801)$ & $1.112(5.387)$ \\
& Losers & $1.109(3.844)$ & $1.003(3.701)$ & $0.968(3.734)$ \\
$J=6$ & $W-L$ & $-0.253(-1.016)$ & $0.012(0.060)$ & $0.144(0.955)$ \\
& Winners & $0.989(4.488)$ & $1.109(5.170)$ & $1.146(5.491)$ \\
& Losers & $0.979(3.388)$ & $0.918(3.277)$ & $0.934(3.495)$ \\
& $W-L$ & $0.010(0.036)$ & $0.190(0.782)$ & $0.212(1.083)$ \\
& Winners & $1.117(5.088)$ & $1.151(5.410)$ & $1.111(5.354)$ \\
& Losers & $0.851(2.790)$ & $0.886(2.989)$ & $0.989(3.488)$ \\
& $W-L$ & $0.267(0.937)$ & $0.264(0.978)$ & $0.121(0.486)$
\end{tabular}

Note(s): This table reports the winners, losers and momentum portfolios. The loser $(L)$ refers to the portfolio with the lowest return in the selection period, while the winner $(W)$ refers to the portfolio with the highest return. Momentum portfolio $(W-L)$ is the difference between winners and losers. For each portfolio, the table shows the portfolio's monthly return constructed following Jagadeesh and Titman (1993) on the basis of their past $J$

Table 3.

Winners, losers and momentum return over 3-12 month horizons periods where $J=3,6$ and 12 and holding the position for the next $K$ periods where $K=3,6$ and 12 using a period of 246 months starting from January 1995. This forms a total of nine portfolios at the intersections between $J$ and $K$. For instance, $J 3-K 3$ is the strategy that is formed according to the returns of the previous three months and held for three after formation. Finally, the figures in parentheses are the $t$-statistics

words, Jegadeesh and Titman (1993) found past winners tend to outperform past losers by $1 \%$ on a monthly basis. Jegadeesh and Titman $(1993,2001)$ attribute this interesting phenomenon to the underreaction bias to new information. In the context of the US HT sector, this finding, however, is consistent with Hameed and Kusnadi (2002) who discovered positive, but insignificant momentum returns. Hameed and Kusnadi (2002) demonstrate that portfolios are formed at the end of ranking periods. As a result, the monthly closing price that we use in the ranking period could be the ask or the bid price. The monthly closing price of the loser is expected to be the bid price. The monthly closing price, however, is expected to be the ask price. They and this research attributed this positive and insignificant return to price reversal that weakens the momentum return over a horizon of three to twelve months. Moreover, the findings of this paper are consistent with Chen et al. (2007) and Leung and Lee (2006) concerning the existence of financial anomalies among the HT stocks. While this paper 
found positive and insignificant momentum in the US HT, Chen et al. (2018) found negative and significant momentum over the short, intermediate and long-term horizons using a sample of Taiwanese hotels.

To check the robustness of the results on momentum, we divided our sample into two subsamples based on size, beta and turnover in Tables A1-A3 in Appendix. This resulted in six subsamples, namely above-median size, below-median size, above-median beta, below-median beta, above-median turnover and below-median turnover. Then, we ran the Jegadeesh and Titman (1993) procedure for each subsample of the six. The vast majority of the robustness checks supported the main results, generating no positive significant momentum returns.

These findings support our hypothesis that the existence of noise trading who committed systematic and behavioral errors may lead to the predictability of US HT stock returns. To be more specific, I discovered short-term reversal resulting from overreaction to news. This overreaction stems from the representative heuristic theory of Tversky and Kahneman (1974). According to this theory, investors overweight recent information while underweight past news. This could result in extravagant pessimism over bad news and lavish optimism over good news. Consequently, stock prices may diverge from the fundamental value in the short-term and create short-term reversal or short-term mean reversion.

\section{Conclusion and discussion}

This research examines the profitability of the momentum investing strategy in the US HT stocks using a sample of 301 US HT stocks and monthly data from the HT firms spanning 246 months of monthly data extracted from the Russell 3,000 index. The methodology of Jegadeesh and Titman (1993) was followed to construct the $J \times K$ momentum portfolios with the formation and holding periods of three, six and 12 months. The paper contributes to the existing literature by offering a simple trading strategy to aid those interested in investing in the US HT sector rather than the complicated models and factors offered in the hospitality finance literature. The findings demonstrated that none of these momentum investing strategies were profitable. Most of the results, however, exhibit positive, yet insignificant momentum returns. These results are robust to size, different formation and holding combinations, beta and turnover and can be attributed to the price reversal over a horizon of three to twelve months in the US HT sector, implying that technical and fundamental analyses may be beneficial tools to predict future returns within the sector.

In the finance literature, the short-term reversal trading strategy has been documented and discussed for more than 40 years. For instance, Jagadeesh (1990) explores that a shortterm reversal strategy which entails buying past losers and selling former winners could produce a monthly profit of $2 \%$ for the period of 1934-1987. Lehmann (1990), on the other hand, utilized the weekly data over the period of 1962-1986 and documents that the shortterm reversal strategy earns $1.79 \%$ per week. The usage of daily data and intraday data returns the same conclusion (Cox and Peterson, 1994; Lin and Xiong, 2018). This phenomenon can be attributed to one of two explanations: first, market makers request compensation for providing liquidity and bearing inventory imbalances (Grossman and Miller, 1988). Second, some behavioralists attributed short-term reversal to the overreaction to information as behavioral bias leading the prices to deviate from the fundamental value and creating mispricing (Shiller 1984; Subrahmanyam 2005).

This research has several important implications in understanding the behavior of the US HT stocks, including the implementation of short-term reversal strategy in practice and in understanding the limitations of efficient market theory (EMT) among the US HT stocks. Theoretically, the EMT holds that stock returns of past information cannot be used to predict future returns. Therefore, the profitable trading strategies in this research are not consistent with the EMT concerning the US HT stocks, and they do challenge the EMT. Moreover, it is 
EJMBE 31,3

\section{8}

possible in the US HT stocks to make abnormal returns through investment trading strategies. This predictability denies the notion of the random walk which is always connected to the EMT.

Random walk is defined as random movements of stock prices resulting from a random and unpredictable production and flow of news. In other words, the notion of the random walk indicates that current price movements are completely independent of past price movements because past news is fully and immediately incorporated into past prices, while current price movements reflect only the currently available news. Therefore, all price movements are unpredictable (Fama, 1998). The existence of short-term reversal and return predictability provides empirical evidence on the failure of random walk. Also, this implies that there are systematic valuation errors among the US HT stocks. All in all, this research opens new doors on the HT sector and may assist researchers of hospitality finance and practitioners better understand some financial phenomena in the US HT stock market.

Practically, this research addresses how far technical and fundamental analyses are useful. Because the market of US HT stocks is not efficient and, in turn, the market prices do not fully reflect the available information (given that new information is incorporated into prices without delay), there is a difference between intrinsic value and market prices because the market cannot estimate the stock value accurately. In this case, where the market is not efficient, both technical analysis, which is the use of historical stock prices to predict the future returns, and fundamental analysis, which is the use of company earning and asset values to predict future returns, may be beneficial and may be expected to generate abnormal returns. Another practical implication of this research, investors and portfolio managers who seek for earning abnormal returns by investing in the US HT stocks can attain their hopes by constructing portfolios based on existing guidelines in the literature and adopting a short-term reversal trading strategy or by buying past losers and selling past winners of the US HT stocks. Overall, the findings impart economically prized information to investors who are interested in the US HT stocks to enable them to better predict the behavior of these stocks.

From a regulation point of view, regulators should consider this mispricing and take actions to improve transparency and dissemination of information to maintain the market efficiency and to reduce behavioral biases in the market. Regarding the research limitations, this paper only considers the US HT sector. Therefore, the extension of results to other developed and developing markets should be taken carefully. Also, this paper relies only on the methodology of Jegadeesh and Titman (1993). Other methodologies could be suitable avenues for future research. There is much room for future investigation of the US HT stocks, including the test of contrarian investing strategies, pair trading strategies and style momentum. Moreover, future research should be conducted into such matters as other financial anomalies, e.g. size effect, value effect, Monday effect and January effect in the US HT stocks. Finally, future researchers could focus on HT in important and unique emerging markets such as China, where the stock market is negatively correlated with the US stock market.

\section{Note}

1. The transportation industry includes railroad transportation, highway passenger transportation, motor freight transportation and warehousing, US postal services, water transportation, transportation by air, pipelines except for natural gas and transportation services. In this paper, we include only transportation by air and transportation services that are considered part of the tourism and hospitality sector. Other subsectors of the transportation sector are ignored.

\section{Rereferces}

Aharon, D.Y. (in press), "Sentiment, confidence and uncertainty: the case of tourism and leisure stocks", Cornell Hospitality Quarterly, pp. 1-14. 
Ahmad, W. and Adaoglu, C. (2018), "Cash management in the travel and leisure sector: evidence from the United Kingdom”, Applied Economics Letters, Vol. 26 No. 7, pp. 618-621.

Barberis, N., Shleifer, A. and Vishny, R. (1998), "A model of investor sentiment”, Journal of Financial Economics, Vol. 49, pp. 307-343.

Barrows, C.W. and Naka, A. (1994), "Use of macroeconomic variables to evaluate selected hospitality stock returns in the US", International Journal of Hospitality Management, Vol. 13, pp. 119-128.

Bloomfield, R., O'Hara, M. and Saar, G. (2009), "How noise trading affects markets: an experimental analysis", Review of Financial Studies, Vol. 22 No. 6, pp. 2275-2302.

Borghesi, R., Annaraud, K. and Singh, D. (2015), “Are hospitality industry IPO stock returns predictable?", International Journal of Hospitality Management, Vol. 44, pp. 23-27.

Brav, A. and Heaton, J. (2002), "Competing theories of financial anomalies", Review of Financial Studies, Vol. 15 No. 2, pp. 575-606.

Chang, C. and Zing, Y.Y. (2011), "Impact of terrorism on hospitality stocks and the role of investor sentiment", Cornell Hospitality Quarterly, Vol. 52 No. 2, pp. 165-175.

Chang, C.-L., Hsu, H.-K. and McAleer, M. (2014), "The impact of China on stock returns and volatility in the Taiwan tourism industry", The North American Journal of Economics and Finance, Vol. 29, pp. 381-401.

Chen, M.H. (2010), "Federal reserve monetary policy and US hospitality stock returns", Tourism Economics, Vol. 16 No. 4, pp. 833-852.

Chen, M.-H. (2012), “A Timing strategy for investments in the US hospitality stocks", Journal of Hospitality and Tourism Research, Vol. 36 No. 3, pp. 283-311.

Chen, M.-H. (2013), "Asymmetric response of hospitality stock prices to Fed policy actions", International Journal of Hospitality Management, Vol. 33, pp. 129-139.

Chen, M.-H., Kim, W.G. and Kim, H.J. (2005), "The impact of macroeconomic and non-macroeconomic forces on hotel stock returns", International Journal of Hospitality Management, Vol. 24 No. 2, pp. 243-258.

Chen, M.-H., Kim, W.G. and Chen, C.-Y. (2007), "An investigation of the mean reversion of hospitality stock prices towards their fundamental values: the case of Taiwan", International Journal of Hospitality Management, Vol. 26, pp. 453-467.

Chen, M.-H., Zhao, Z., Wang, K. and Lv, W.Q. (2018), "The momentum effect on Taiwanese hotel stocks", International Journal of Hospitality Management, Vol. 71, pp. 141-150.

Cheung, W.M.Y. and Lam, D. (2015), "Comparing the price of sin: abnormal returns of cross-listed casino gaming stocks in the Hong Kong and US markets", International Journal of Hospitality Management, Vol. 45, pp. 73-76.

Chui, A.C., Titman, S. and Wei, K.C.J. (2003), "Intra-industry momentum: the case of REITs", Journal of Financial Markets, Vol. 6 No. 3, pp. 363-387.

Collier, P. and Gregory, A. (1995), "Investment appraisal in services industries: a field study analysis of the UK hotel sector", Management Accounting Research, Vol. 6, pp. 33-57.

Conrad, J. and Kaul, G. (1998), “An anatomy of trading strategies”, Review of Financial Studies, Vol. 11, pp. 489-519.

Cox, D.R. and Peterson, D.R. (1994), "Stock returns following large one-day declines: evidence on the short-term reversals and long-term performance", The Journal of Finance, Vol. 49, pp. 255-267.

Daniel, K., Hirshleifer, D. and Subrahmanyam, A. (1998), "Investor psychology and security market under-and oveereactions”, The Journal of Finance, Vol. 53, pp. 1839-1885.

De Bondt, W.F.M. and Thaler, R.H. (1985), "Does the stock market overreact?”, The Journal of Finance, Vol. 40 No. 3, pp. 793-805.

Demir, E., Alıc1, Z.A. and Lau, M.C.K. (2017), "Macro explanatory factors of Turkish tourism companies' stock returns", Asia Pacific Journal of Tourism Research, Vol. 22 No. 4, pp. 370-380.

Momentum investing 
EJMBE 31,3

Dewally, M., Flaherty, S. and Shao, Y. (2017), "Determinants of financial policy in the hospitality sector in the United States", Tourism Economics, Vol. 23 No. 3, pp. 523-542.

Erb, C.B. and Campbell, H.R. (2006), "The strategic and tactical value of commodity futures", Financial Analyst Journal, Vol. 62, pp. 78-101.

Ersan, O., Akron, S. and Demir, E. (2019), "The effect of European and global uncertainty on stock returns of travel and leisure companies", Tourism Economics, Vol. 25, pp. 51-66.

Fama, E.F. (1965), “The behavior of stock market prices”, Journal of Business, Vol. 38 No. 1, pp. 34-105.

Fama, E.F. (1998), "Market efficiency, long-term returns, and behavioral finance", Journal of Financial Economics, Vol. 49, pp. 283-306.

Goukasian, L., Ma, Q. and Majbouri, M. (2012), "The monetary policy risks of hospitality stocks", Cornell Hospitality Quarterly, Vol. 53 No. 4, pp. 339-346.

Grinblatt, M. and Han, B. (2005), "Prospect theory, mental accounting and momentum", Journal of Financial Accounting, Vol. 78, pp. 311-339.

Grossman, S. and Miller, M. (1988), "Liquidity and market structure”, The Journal of Finance, Vol. 43, pp. 617-633.

Hameed, A. and Kusnadi, Y. (2002), "Momentum strategies: evidence from Pacific basin stock markets", Journal of Financial Research, Vol. 25 No. 3, pp. 383-397.

Hsu, P.-P. (2017), "Examination of Taiwan's travel and tourism market cycle through a two-period Markov regime-switching model”, Tourism Management, Vol. 63, pp. 201-208.

Jagadeesh, N. (1990), "Evidence of predictable behavior of security returns", The Journal of Finance, Vol. 45, pp. 881-898.

Jalkh, N., Bouri, E., Vo, X.V. and Dutta, A. (in press), "Hedging the risk of travel and leisure stocks: the role of crude oil", Tourism Economics.

Jareno, F., Escribano, A. and Torres, M.P. (in press), “Analysis of stock returns of main European service and tourism companies", Tourism Economics, pp. 1-31.

Jegadeesh, N. and Titman, S. (1993), "Returns to buying winners and selling losers: implications for stock market efficiency", The Journal of Finance, Vol. 48, pp. 65-91.

Jegadeesh, N. and Titman, S. (2001), "Profitability of momentum strategies: an evaluation of alternative explanations", The Journal of Finance, Vol. 56 No. 2, pp. 699-720.

Keynes, J. (1936), The General Theory of Employment, Interest and Money, Macmillan, London.

Kim, H.S. and Jang, S.S. (2018), "Does hotel ownership structure influence capital expenditures?", Cornell Hospitality Quarterly, Vol. 59 No. 4, pp. 325-339.

Kim, J., Kim, H. and Woods, D. (2011), "Determinants of corporate cash-holding levels: an empirical examination of the restaurant industry", International Journal of Hospitality Management, Vol. 30, pp. 568-54.

Lee, J.-S. and Jang, S. (2007), "The systematic-risk determinants of the US airline industry”, Tourism Management, Vol. 28, pp. 434-442.

Lee, W.S., Moon, J., Lee, S. and Kerstetter, D. (2013), "Determinants of systematic risk in the online travel agency industry", Tourism Economics, Vol. 21 No. 2, pp. 341-355.

Lehmann, B. (1990), "Fads, martingales, and market efficiency", Quarterly Journal of Economics, Vol. 105, pp. 1-28.

Leung, W.K. and Lee, T.S. (2006), "Institutional investors and the Monday effect on tourism stocks", International Journal of Hospitality Management, Vol. 25, pp. 348-372.

Li, Y. and Singal, M. (2019), "Capital structure in the hospitality industry: the role of the asset-light and fee-oriented strategy", Tourism Management, Vol. 70, pp. 124-133.

Lim, C. and Chan, F. (2013), "An empirical modelling of New Zealand hospitality and tourism stock returns”, ISRN Economics, Vol. 3, pp. 1-10. 
Lin, S. and Xiong, X. (2018), "Intraday reversal, liquidity and anchored expectation”, available at: http://cfrc. pbcsf.tsinghua.edu.cn/Public/Uploads/upload/CFRC2019_1680.pdf (accessed 9 September 2020).

Moskowitz, T.J. and Grinblatt, M. (2002), "Do industries explain momentum?”, The Journal of Finance, Vol. 54 No. 4, pp. 1249-1290.

Nowak, L.S. (1993), Monetary Policy and Investment Opportunities, Quorum Books, Westport, CT.

Oak, S. and Dalbor, M.C. (2008), "Institutional investor preferences for lodging stocks", International Journal of Hospitality Management, Vol. 27, pp. 3-11.

Qin, Y., Chen, J. and Dong, X. (2021), "Oil prices, policy uncertainty and travel and leisure stocks in China”, Energy Economics, Vol. 96 April.

Ritter, J.R. (2003), "Behavioral finance”, Pacific-Basin Finance Journal, Vol. 11, pp. 429-437.

Rouwenhorst, K.G. (1998), "International momentum strategies", The Journal of Finance, Vol. 53 No. 1, pp. 267-284.

Rouwenhorst, G.K. (1999), "Local return factors and turnover in emerging stock markets", The Journal of Finance, Vol. 54 No. 2, pp. 1439-1464.

Sadka, R. (2006), "Momentum and post-earnings-announcement drift anomalies: the role of liquidity risk", Journal of Financial Economics, Vol. 80 No. 2, pp. 309-349.

Shahzad, S.J.H. and Caporin, M. (2020), "On the volatilities of tourism stocks and oil", Annals of Tourism Research, Vol. 81, pp. 102705-102708.

Shiller, R.J. (1984), “Stock prices and social dynamics”, Brookings Papers on Economic Activity, Vol. 2, pp. $457-510$.

Shleifer, A. (2000), Inefficient Markets: An Introduction to Behavioral Finance, Oxford University Press, New York.

Shleifer, A. and Vishny, R.W. (1997), “The Limits of arbitrage”, The Journal of Finance, Vol. 52 No. 1, pp. 35-55.

Singal, M. (2012), "Effect of consumer sentiment on hospitality expenditures and stock returns", International Journal of Hospitality Management, Vol. 31, pp. 511-521.

Subrahmanyam, A. (2005), "Distinguishing between rationales for short-term horizon predictability of stock returns", Financial Review, Vol. 40, pp. 11-35.

Tversky, A. and Kahneman, D. (1974), "Judgment under uncertainty: heuristics and biases", Science, Vol. 185, pp. 1124-1131.

US Travel Association (2017), "US travel and tourism overview", available at: https://www.ustravel. org/system/files/media_root/document/Research_Fact-Sheet_US-Travel-and-TourismOverview.pdf.

\section{Further reading}

Friedrich, E.A. (2020), available at: https://scholar.sun.ac.za/bitstream/handle/10019.1/4373/friedrich_ profitability_2010.pdf? sequence $=1$ \&isAllowed $=\mathrm{y}$.

Malkiel, B.G. (2003), "The efficient market hypothesis and its critics", The Journal of Economic Perspectives, Vol. 17 No. 1, pp. 59-82.

Napierała, T. and Szutowski, D. (2019), "The impact of localized innovations on the stock returns of tourism companies", International Journal of Tourism Research, Vol. 21, pp. 108-121.

\section{Corresponding author}

Mohamed Shaker Ahmed can be contacted at: mashaker@foc.cu.edu.eg
Momentum investing 


\section{EJMBE 31,3 \\ Appendix \\ Robustness analysis}

282

Table A1.

Winners, losers and momentum return over 3-12 months horizons for above median size stocks and below median size stocks in sequence 


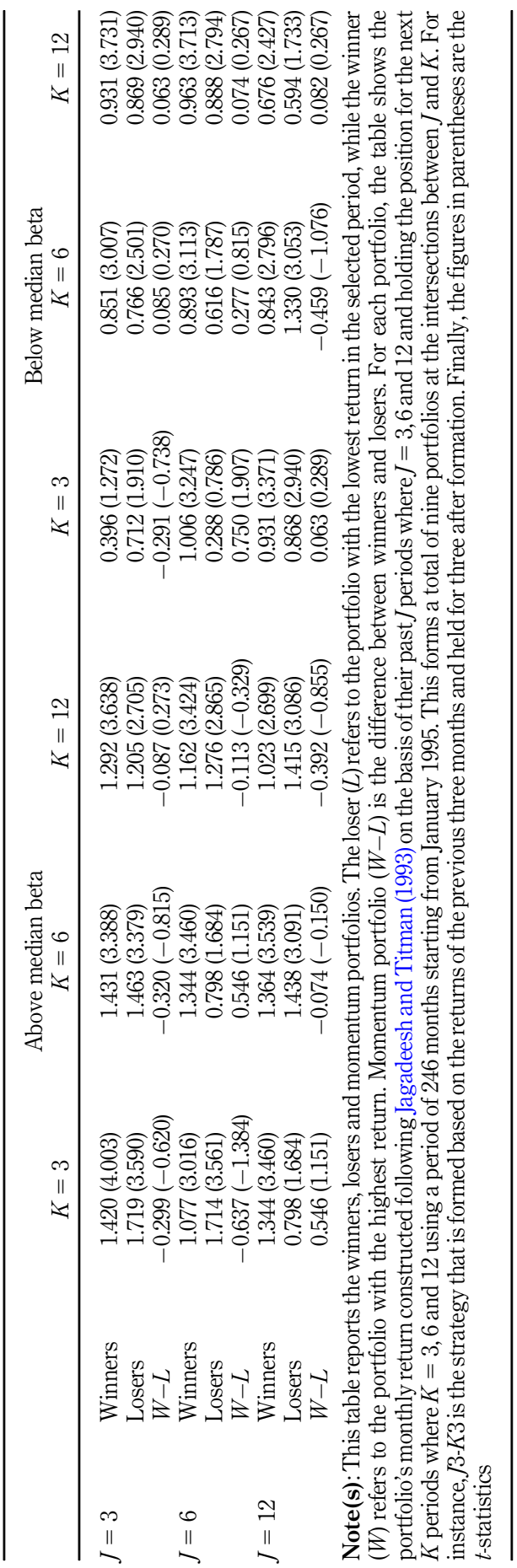

Momentum investing

283

Table A2.

Winners, losers and momentum return over 3-12 month horizons for above median beta stocks and below median beta in sequence 
EJMBE

31,3

\section{4}

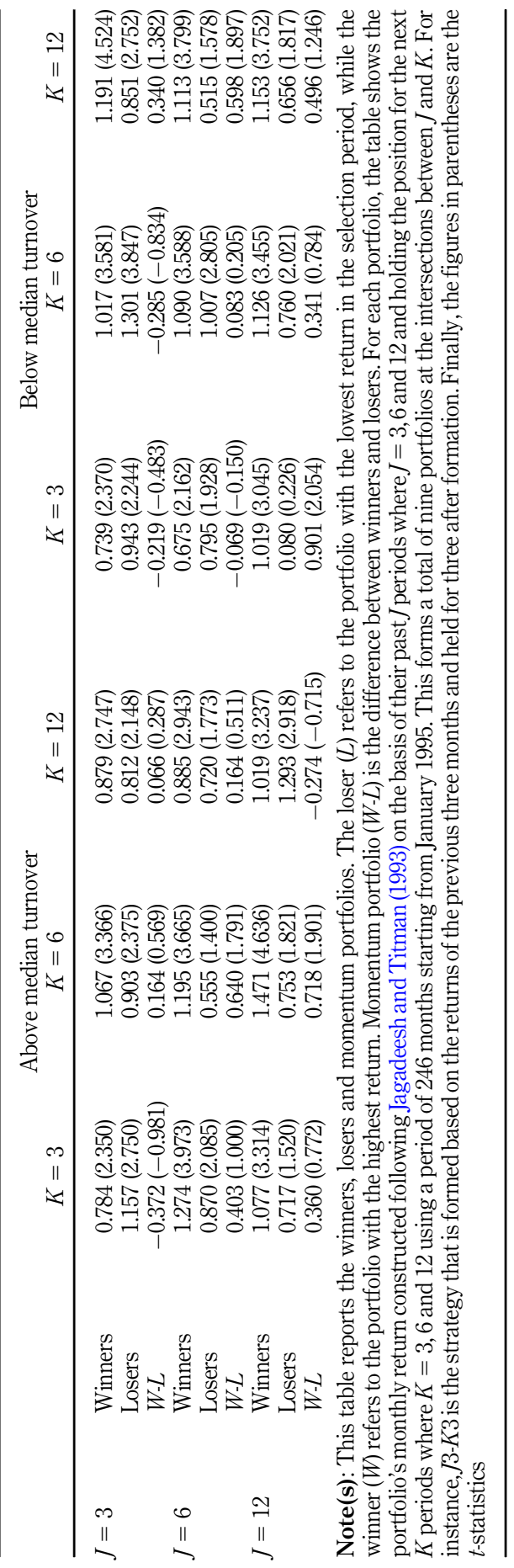

Table A3.

Winners, losers and momentum return over 3-12 months horizons for above median turnover stocks and below median turnover in sequence 